\title{
CORRESPONDENCE
}

\section{Help with Protein}

SIR,- "How to help with protein" (Nature, 236, 1; 1972) is an excellent review of the protein problem, but it misses the important point, that perhaps protein deficiency is not the most serious problem after all, even for young children. The United Nations document "Feeding the expanding world population: international action to avert the impending protein crisis" (UN Publication E. 68, xiii, 2) appeared just at a time when many workers in the field of nutrition were beginning to question the almost exclusive concentration on protein which had characterized the previous decade. It is not accepted by all that kwashiorkor can be equated simply with protein deficiency; some believe that it represents a failure of adaptation to a generally poor diet, others that the precipitating factor is an infection. When energy rather than protein is the limiting factor in the diet, the end result is marasmus, which is less dramatic than kwashiorkor, and has therefore received less attention. Broadly speaking, kwashiorkor may perhaps be regarded as a disease of rural communities, marasmus of urban ones. With rapidly increasing urbanization in most developing countries, marasmus is becoming an ever more serious problem. Since it tends to occur at an earlier age than kwashiorkor, the permanent effects on development are more likely.

Your article was stimulated by the Eighth Report of the Joint Expert Committee on Nutrition of FAO and WHO, which it describes as disappointing. Certainly the report does not give a clear picture of the problem, because there are too many gaps in our knowledge. The report poses two questions: first, can one diagnose the nature and extent of the dietary deficiency from the clinical pattern protein-calorie malnutrition? Second, how can one assess the prevalence and type of protein-calorie malnutrition in any community? The answer to these two questions is essential for the proper planning of preventive measures. It may well turn out that concentration on the "protein gap", and on the practical difficulties of what you describe as artificially fortified foods is leading us down a blind alley. It is necessary to keep an open mind.

In fact your article does this admirably in its closing paragraphs. "It follows that the mere provision of protein supplements is not sufficient and that developing countries ... have no way of meeting the social need which confronts them except by developing the kinds of child care services which can ensure that suitable foods are available at the critical times. ... Such programmes . . . will have to deal not merely with protein supplements but with the health care of children in the round". These words deserve to be quoted again and again because, as you rightly point out, it is useless to treat these problems in isolation.

Yours faithfully,

\section{J. C. WATERLow}

London School of Hygiene

and Tropical Medicine,

Keppel Street (Gower Street), London WC1E $7 \mathrm{HT}$

\section{Rothschild}

SIR,-Winding up for the Government in the House of Lords debate on the Rothschild Report on February 29, Earl Jellicoe said (about the Research Councils vis-à-vis executive departments) that he saw "no reason why there should be a confrontation ... between opposing forces" and that he thought he could predict with some confidence that we shall follow "the evolutionary path which I think many noble Lords have suggested we should tread on this particular matter".

What evolutionary path can we tread? The best answer is to replace the blunderbuss of Table IV of Lord Rothschild's Report by inter-governmental machinery in which the research councils would be included.

All parties are agreed on the transfer to executive departments of the financial responsibility for most of the tactical science done by the research councils, once the departments have fully competent Chief Scientist organizations. This could in due course transfer funds of $£ 7$ or $£ 8$ million. The work involved can be fairly easily defined and identified, and the transfer would not raise problems of accountability or threaten the stability or integrity of the councils.

To go beyond transfers of this magnitude involves arguments about strategic and basic research where different but equally valid definitions give different answers. Moreover, the transfer to executive departments of funds with which the research councils finance basic and strategic research cannot but cut across their ability to discharge their primary responsibilities, which are to the Secretary of State for Education and Science.

In any case, the objective of organizations is that executive departments should be able effectively to infiuence thd programmes of the councils so as to take account of national responsibilities of the departments in the same or related fields of research. In that case, there are two steps on which all the parties are agreedthe creation of powerful Chief Scientists' organizations within departments and the granting of full council membership to the heads of those organizations. These two developments would go a long way to securing the main objective. True, such an arrangement would entail partnership and joint involvement, as opposed to the method of confrontation which would almost certainly result from giving departments the power of the purse, and good will and good sense by all would be required, but that is not a weaknessrather a necessity for any organization to run well.

But what will happen when a department and a research council disagree about a programme or series of programmes, or where a department considers that too much money is being allocated to the research councils as a whole? At present there is no machinery for catering for this kind of situation. The advice of the Council for Scientific Policy goes straight to the Secretary of State for Education and Science, who deals directly with the Treasury. There is no place, and no point in time, at which departments can quarrel with the amount of money being allocated to the DES vote. This is the one remaining gap in the machinery which must be closed.

So should not departments have the right to take major disagreements on research council programmes or financial allocations direct to the CSP? The CSP should make its own judgment of such a dispute in framing its advice to the Secretary of State, making clear in every case what the respective arguments are and why they have decided the one way or the other. It is to ensure that the CSP should not automatically rubber stamp the views of the research councils in such a situation that this institution, while wishing the CSP to remain advisory, has supported the proposal of the Dainton Working Party that the Chief Scientists of Departments should also be members of the CSP. The Cabinet would, of course, be the ultimate referee.

It is, surely, along these lines that a solution must evolve. Instead of arbitrarily wresting from the councils a large part of the finance they have already secured to discharge their responsibilities to the Secretary of State for Education and Science, machinery must be created 